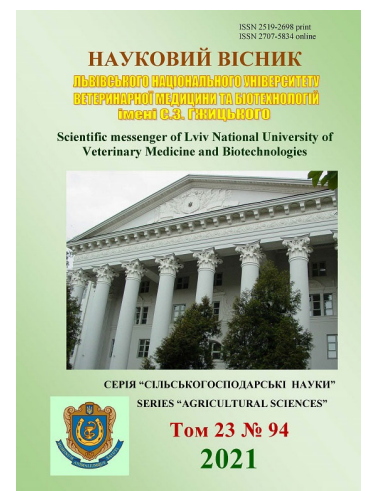

Науковий вісник Дьвівського національного університету ветеринарної медицини та біотехнодогій імені С.3. Гжицыкого. Серія: Сільськогосподарські науки

\author{
Scientific Messenger of Lviv National University \\ of Veterinary Medicine and Biotechnologies. \\ Series: Agricultural sciences
}

ISSN 2519-2698 print ISSN 2707-5834 online doi: 10.32718/nvlvet-a9418

https://nvlvet.com.ua/index.php/agriculture

UDC 631.1. 636

\title{
Methodical approaches to assessing the effectiveness of animal husbandry
}

\author{
R. M. Myniv
}

Stepan Gzhytskyi National University of Veterinary Medicine and Biotechnologies Lviv, Lviv Ukraine

Article info

Received 23.02.2021

Received in revised form 22.03.2021

Accepted 23.03.2021

Stepan Gzhytskyi National University of Veterinary Medicine and Biotechnologies Lviv, Pekarska Str., 50, Lviv, 79010, Ukraine. Tel.: +38-067-370-43-92 E-mail:muniv@ukr.net
Myniv, R. M. (2021). Methodical approaches to assessing the effectiveness of animal husbandry. Scientific Messenger of Lviv National University of Veterinary Medicine and Biotechnologies. Series: Agricultural sciences, 23(94), 100-105. doi: 10.32718/nvlvet-a9418

Economic efficiency of livestock production is determined using a system of indicators, among which the main (generalizing) indicator of economic efficiency of livestock production is the achieved level of labor productivity. This indicator has a significant impact on other derivative indicators. A comprehensive assessment of the efficiency of farming systems should be carried out using a generalized indicator of the efficiency of the used resources of the livestock enterprise and an indicator of the share of growth of livestock products. The matrix method is the most acceptable for the analysis and an estimation of efficiency of work of the livestock enterprises. It allows: to rank livestock enterprises according to the achieved level of efficiency (static task); to study changes in the level of efficiency of livestock enterprises during the analyzed period (dynamic task); determine the dependence of farm performance on intensive and extensive factors. To assess the economic efficiency of feed production in animal husbandry use the indicator "marginal productivity of feed (feed protein) unit". Evaluation of productive use of dairy cows is carried out using the coefficient of productivity intensity, which is calculated by the ratio of the average milk yield per day to the lifetime milk yield of cows. The complexity of livestock mechanization, individual technological lines or specific machines and equipment is determined by the calculated technical and economic indicators, comparing them with the indicators obtained in practice of the existing facility or basic analogue, or with the best examples of domestic or world practice. The application of the above indicators of analysis and evaluation of livestock efficiency will provide: assessment of the effectiveness of production systems by livestock enterprises in modern conditions of their development; objective characteristics of farming and the main results of activities in animal husbandry; identification of the most rational options for improving the efficiency of animal husbandry; comparative assessment of the efficiency of livestock enterprises operating in the same natural and economic conditions; measuring production efficiency in livestock and related industries; identification and evaluation of a set of measures for the development of animal husbandry aimed at improving the efficiency of its operation.

Key words: efficiency, animal husbandry, evaluation, indicator.

\section{Методичні підходи до оцінки ефективності тваринництва}

\author{
Р. М. Минів
}

Львівський національний університет ветеринарної медицини та біотехнологій імені С. 3. Гжицького, м. Львів, Україна

Економічну ефективність виробництва в тваринництві визначають із використанням системи показників, серед яких головним (узагальнюючим) показником економічної ефективності виробництва продукиї тваринництва є досягнутий рівень продуктивності праці. Цей показник здійснює значний вплив на решту похідних показників. Комплексна оцінка ефективності систем ведення господарства проводитися за допомогою узагальнюючого показника ефективності використовуваних ресурсів тваринницького підприємства та показника частки приросту продукції тваринництва. Для аналізу й оцінки ефективності роботи тваринницьких підприємств найбільш прийнятний матричний метод. Він дозволяє: ранжувати тваринницькі підприємства за досягнутим рівнем ефективності (статична задача); досліджувати зміни рівня ефективності тваринницьких підприємств протягом аналізованого періоду (динамічна задача); визначати залежність результатів роботи ферми від інтенсивних й екстенсивних факторів. Для 
оцінювання економічної ефективності кормовиробництва у тваринництві використовують показник “граничної продуктивності кормової (кормопротеїнової) одиниці”. Оџінку продуктивного використання молочних корів здійснюють за допомогою коефіцієнта інтенсивності продуктивності, який розраховують відношенням середнього надою за одну добу до пожиттєвого надою корови. Комплексність механізації тваринництва, окремих технологічних ліній чи конкретних машин $і$ обладнання визначають за розрахунковими техніко-економічними показниками, порівнюючи їх з отриманими на практиці показниками діючого об'єкту чи базового аналога або з показниками кращих зразків вітчизняної чи світової практики. Застосування розглянутих вище показників аналізу та оцінки ефективності тваринництва дозволить забезпечити: оцінку ефективності систем ведення виробництва тваринницькими підприємствами в сучасних умовах їх розвитку; об'єктивну характеристику ведення господарства та головних результатів діяльності в тваринництві; визначення найбільш раціональних варіантів підвищення ефективності тваринництва; порівняльну оцінку ефективності тваринницьких підприємств, щчо працюють в однакових природно-економічних умовах; вимір ефективності виробництва у тваринництві та суміжних галузях; виявлення та оцінку комплексу заходів розвитку тваринництва, спрямованих на підвищення ефективності його функціонування.

Ключові слова: ефективність, тваринництво, оцінка, показник.

\section{ВстуII}

Ефективність виробництва полягає у тому, щоб на кожну одиницю матеріальних, трудових і фінансових витрат істотно збільшувати обсяг виробництва і доходу шляхом зниження матеріаломісткості, скорочення трудових витрат і значного підвищення якості продукції. Лише на цій основі можна успішно вирішувати економічні та соціальні проблеми регіону, країни. Тому важливо, щоб такий аналіз здійснювався загалом по господарству, кожному підрозділу не тільки за підсумками року, де можливо, поквартально, й помісячно, щоб поточний виробничий процес був під постійним контролем, а висновки оперативного аналізу можна було б використовувати для коригування поточних господарських операцій. У зв'язку з цим головна увага статистичного аналізу повинна приділятися виявленню закономірностей та потенційних резервів, особливо визначенню чинників і шляхів підвищення економічної ефективності сільськогосподарського виробництва в різних за формою і змістом підприємствах (Kostetskyi, 2013).

У практиці господарювання вітчизняних підприємств набула широкого застосування система показників ефективності сільськогосподарського виробництва, яка певною мірою відмінна від тієї, що використовується в більшості розвинутих країн світу. Це призводить до суперечностей в оцінках ефективності діяльності окремих суб'єктів господарювання, їх організаційних форм та галузей загалом, у зв'язку з чим виникає потреба всебічного наукового обгрунтування залежності ефективності фінансово-господарської діяльності від впливу сукупності різноманітних чинників (Lysenko \& Lysenko, 2009).

Особливістю методології наукового дослідження є те, що вона може складатися не лише з методів, принципів і прийомів, що $є$ специфічними для науки, в межах якої здійснюється дане дослідження, а й такі, що розроблені іншими науками. Змістовність методології наукового дослідження визначають насамперед iii методи. Але водночас важливу роль відіграють також принципи - ті важливі вимоги, яких потрібно дотримуватися в процесі наукового пізнання, щоб досягти поставленої мети (Andriichuk, 2016).

\section{Результати та їх обговорення}

Для оцінки рівня ефективності у тваринництві прийнято використовувати такі показники: рівень продуктивності тварин; частка високопородних тварин у загальному поголів'ї; витрата кормів на одиницю продукції; сукупні витрати тваринництва на 1 умовну голову; вартість виробничих фондів тваринництва у розрахунку на 1 умовну голову; величина поточних виробничих витрати тваринництва на 1 умовну голову або 1 голову основного стада; продуктивність праці (трудомісткість); рівень механізації виробничих процесів у тваринництві; собівартість одиниці продукції; сума прибутку від застосування інтенсивних технологій; рівень рентабельності виробництва тваринницької продукції (Radko \& Svynous, 2015).

Економічну ефективність виробництва в тваринництві визначають із використанням системи показників, серед яких головним (узагальнюючим) показником економічної ефективності виробництва продукції тваринництва є досягнутий рівень продуктивності праці. Цей показник здійснює значний вплив на решту похідних показників (рис. 1).

Комплексна оцінка ефективності систем ведення господарства може проводитися за допомогою узагальнюючого показника. Він забезпечує оцінку систем, насамперед відповідно до основного критерію - максимізації виробництва сільськогосподарської продукції на основі повного використання створеного в аграрному виробництві потенціалу при найменших витратах, а також підвищення рівня соціального розвитку села, збереження довкілля (Livinskyi, 2019).

Узагальнюючий показник ефективності використовуваних ресурсів тваринницького підприємства (Езр) розраховують за формулою:

$$
E_{3 Р}=\frac{V_{\text {पП }}}{\mathrm{U}_{\Pi}+\left(\Phi_{03}+\Phi_{\text {ОБ }}\right) \times K_{\Pi в \Pi}}
$$

Vчп - обсяг чистої продукції ;

Чп - чисельність працівників;

Фоз - середньорічний обсяг основних засобів;

Фоб - вартість оборотних засобів;

Кпвп - коефіцієнт повних витрат праці.

Показник частки приросту продукції тваринництва розраховують за формулою:

$$
\mathrm{Ч}_{\mathrm{IHT}}=\left(1-\frac{\Delta \mathrm{P}_{3}}{\Delta V_{\mathrm{B}}}\right) \times 100
$$

де 
Чінт - частка приросту обсягу продукції

$\Delta \mathrm{P}_{3}$ - приріст застосовуваних ресурсів за певний період;

$\Delta \mathrm{V}_{\text {в }}$ - приріст обсягу виробництва продукції за цей же період (рік), \%.

Для аналізу й оцінки ефективності роботи тваринницьких підприємств найбільш прийнятний матричний метод.
Матричний метод дозволяє:

- ранжувати тваринницькі підприємства за досягнутим рівнем ефективності (статична задача);

- досліджувати зміни рівня ефективності тваринницьких підприємств протягом аналізованого періоду (динамічна задача);

- визначати залежність результатів роботи ферми від інтенсивних й екстенсивних факторів (Livinskyi, 2019).

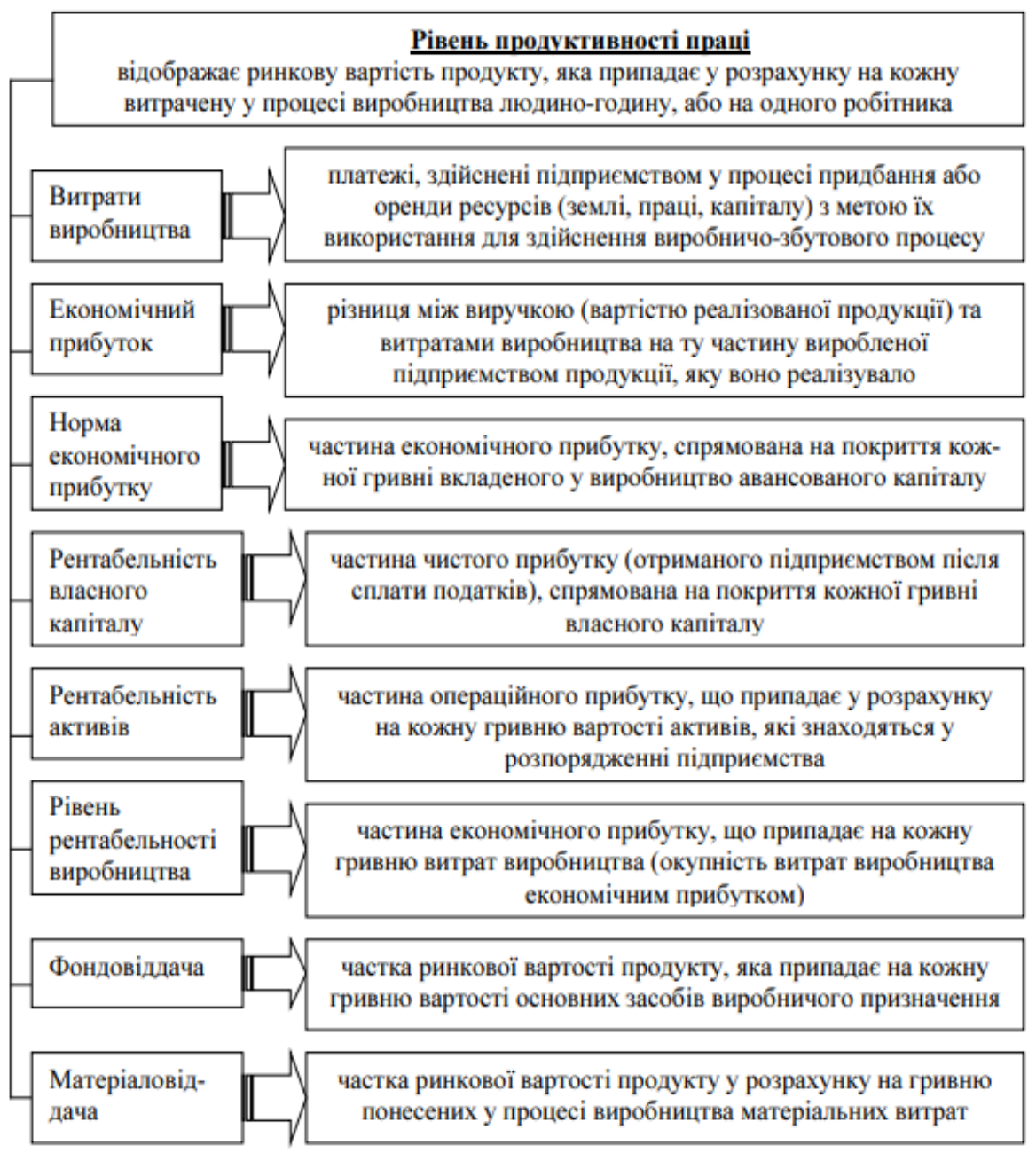

Рис. 1. Похідні показники абсолютного ефекту та рівня ефективності тваринництва від продуктивності праці

Для оцінки ефективності тваринництва використовують ключову матрицю (табл. 1).

Для побудови моделі використовують матеріали Державної служби статистики та звітність тваринницьких підприємств (виробнича площа, витрати електроенергії тощо).

Матричний метод для оцінки та аналізу тваринництва дозволяє ранжувати підприємства за рівнем ефективності на основі синтетичних показників та досліджувати іï зміни за часом.

Критерієм ефективності кормовиробництва слугує абсолютна різниця між граничною ціною кормової (кормопротеїнової) одиниці та іiї фактичною собівартістю, визначеною з урахуванням якості продукції тваринництва.
Відносний показник відповідності фактичного рівня собівартості 1 ц корм. од. граничній величині характеризує ефективність виробництва кормів за фактичного рівня цін на продукцію тваринництва й відображає граничну величину зростання собівартості кормів у відсотках (Petrychenko \& Petrychenko, 2017).

Ефективність кормовиробництва у тваринництві розраховують за формулою:

$$
\mathrm{E}=\frac{\Pi_{\Gamma \mathrm{p}}-\Pi_{\phi}}{\Pi_{\phi}} \times 100
$$

де:

Е - ефективність кормовиробництва, \%;

$\Pi_{\phi}$ - фактична вартість кормової одиниці, грн. 
Таблиця 1

Матриця оцінки ефективності тваринництва

\begin{tabular}{|c|c|c|c|c|c|c|}
\hline & Прибуток, грн & $\begin{array}{c}\text { Виторг, } \\
\text { грн }\end{array}$ & $\begin{array}{c}\text { Обсяги вироб- } \\
\text { ництва, кг }\end{array}$ & $\begin{array}{c}\text { Витрати кор- } \\
\text { мів, корм од }\end{array}$ & $\begin{array}{c}\text { Виробничі } \\
\text { витрати, } \\
\text { грн } \\
\end{array}$ & $\begin{array}{c}\text { Витрати } \\
\text { ел. Енергії, } \\
\text { квт-год } \\
\end{array}$ \\
\hline Прибуток, грн & & $\begin{array}{c}\text { Виторг } \\
\text { на } 1 \text { грн при- } \\
\text { бутку } \\
\end{array}$ & $\begin{array}{c}\text { Вироблено на } \\
1 \text { грн прибутку }\end{array}$ & $\begin{array}{c}\text { Витрата кормів } \\
\text { на } 1 \text { грн при- } \\
\text { бутку } \\
\end{array}$ & $\begin{array}{c}\text { Виробничі } \\
\text { витрати на } 1 \\
\text { грн прибутку }\end{array}$ & $\begin{array}{c}\text { Витрата } \\
\text { ел.енергії на } 1 \\
\text { грн прибутку } \\
\end{array}$ \\
\hline $\begin{array}{c}\text { Виторг від } \\
\text { виробництва } \\
\text { продукції, грн }\end{array}$ & $\begin{array}{c}\text { Рентабельність } \\
\text { продукції }\end{array}$ & & $\begin{array}{c}\text { Вироблено } \\
\text { продукції на } 1 \\
\text { грн виторгу }\end{array}$ & $\begin{array}{c}\text { Витрата кормів } \\
\text { на } 1 \text { грн } \\
\text { продукції }\end{array}$ & $\begin{array}{c}\text { Виробничі } \\
\text { витрати } \\
\text { на } 1 \text { грн про- } \\
\text { дукції } \\
\end{array}$ & $\begin{array}{c}\text { Витрати ел. } \\
\text { енергіï на } 1 \text { грн } \\
\text { продукції }\end{array}$ \\
\hline $\begin{array}{c}\text { Вироблено } \\
\text { продукції, кг }\end{array}$ & $\begin{array}{l}\text { Рентабельність } \\
1 \text { кг продукції }\end{array}$ & $\begin{array}{c}\text { Середня ціна } \\
\text { продукції }\end{array}$ & & $\begin{array}{c}\text { Витрати кор- } \\
\text { мів на } 1 \text { кг } \\
\text { продукції }\end{array}$ & $\begin{array}{c}\text { Виробничі } \\
\text { витрати на } 1 \text { кг } \\
\text { продукції }\end{array}$ & $\begin{array}{c}\text { Витрати } \\
\text { ел. енергії } \\
\text { на } 1 \text { кг проду- } \\
\text { кції } \\
\end{array}$ \\
\hline $\begin{array}{l}\text { Витрати кор- } \\
\text { мів, корм. од. }\end{array}$ & $\begin{array}{c}\text { Рентабельність } \\
\text { кормів }\end{array}$ & $\begin{array}{c}\text { Виторг на } 1 \\
\text { корм. од. }\end{array}$ & $\begin{array}{c}\text { Вироблено } \\
\text { продукції на } 1 \\
\text { корм. од. } \\
\end{array}$ & & $\begin{array}{c}\text { Виробничі } \\
\text { витрати на } 1 \\
\text { корм. од. } \\
\end{array}$ & $\begin{array}{c}\text { Витрати ел. } \\
\text { енергії на } 1 \\
\text { корм. од. } \\
\end{array}$ \\
\hline $\begin{array}{c}\text { Виробничі } \\
\text { витрати (BВ), } \\
\text { грн } \\
\end{array}$ & $\begin{array}{c}\text { Рентабельність } \\
\text { ВВ }\end{array}$ & $\begin{array}{c}\text { Виторг на } 1 \\
\text { грн ВВ }\end{array}$ & $\begin{array}{c}\text { Вироблено } \\
\text { продукції } \\
\text { на } 1 \text { грн ВВ }\end{array}$ & $\begin{array}{c}\text { Витрати кор- } \\
\text { мів на } 1 \text { грн } \\
\text { BВ } \\
\end{array}$ & & $\begin{array}{c}\text { Витрати ел. } \\
\text { енергії на } 1 \text { грн } \\
\text { ВВ } \\
\end{array}$ \\
\hline $\begin{array}{c}\text { Витрата ел. } \\
\text { енергії, } \\
\text { квт-год } \\
\end{array}$ & $\begin{array}{l}\text { Рентабельність } \\
\text { електроенергії }\end{array}$ & $\begin{array}{c}\text { Виторг на } 1 \\
\text { квт-год }\end{array}$ & $\begin{array}{c}\text { Вироблено } \\
\text { продукції } \\
\text { на } 1 \text { квТ-год }\end{array}$ & $\begin{array}{c}\text { Витрати кор- } \\
\text { мів на } \\
1 \text { квт-год } \\
\end{array}$ & $\begin{array}{c}\text { Виробничі } \\
\text { витрати на } \\
1 \text { квт-год } \\
\end{array}$ & \\
\hline $\begin{array}{c}\text { Вартість обла- } \\
\text { днання, грн }\end{array}$ & $\begin{array}{c}\text { Рентабельність } \\
\text { обладнання }\end{array}$ & $\begin{array}{c}\text { Виторг } \\
\text { на } 1 \text { грн. } \\
\text { обладання }\end{array}$ & $\begin{array}{c}\text { Вироблено } \\
\text { продукції } \\
\text { на } 1 \text { грн. обла- } \\
\text { днання } \\
\end{array}$ & $\begin{array}{c}\text { Витрати кор- } \\
\text { мів } \\
\text { на } 1 \text { грн. обла- } \\
\text { днання } \\
\end{array}$ & $\begin{array}{c}\text { Виробничі } \\
\text { витрати на } 1 \\
\text { грн обладнан- } \\
\text { ня } \\
\end{array}$ & $\begin{array}{c}\text { Витрати } \\
\text { ел.енергії на } 1 \\
\text { грн облад-ня }\end{array}$ \\
\hline Зарплата, грн & $\begin{array}{c}\text { Рентабельність } \\
\text { зарплати }\end{array}$ & $\begin{array}{c}\text { Виторг на } 1 \\
\text { грн зарплати }\end{array}$ & $\begin{array}{c}\text { Вироблено } \\
\text { продукції } \\
\text { на } 1 \text { грн зар- } \\
\text { плати }\end{array}$ & $\begin{array}{c}\text { Витрати кор- } \\
\text { мів на } 1 \text { грн } \\
\text { зарплати }\end{array}$ & $\begin{array}{c}\text { Виробничі } \\
\text { витрати на } 1 \\
\text { грн зарплати }\end{array}$ & $\begin{array}{c}\text { Витрати } \\
\text { ел.енергії } \\
\text { на } 1 \text { грн зар- } \\
\text { плати }\end{array}$ \\
\hline $\begin{array}{c}\text { Витрати праці, } \\
\text { люд.-год }\end{array}$ & $\begin{array}{c}\text { Рентабельність, } \\
\text { люд.-год }\end{array}$ & $\begin{array}{c}\text { Виторг } \\
\text { на } 1 \text { люд.-год }\end{array}$ & $\begin{array}{c}\text { Вироблено } \\
\text { продукції на } 1 \\
\text { люд.-год } \\
\end{array}$ & $\begin{array}{c}\text { Витрати кор- } \\
\text { мів на } 1 \text { люд.- } \\
\text { год } \\
\end{array}$ & $\begin{array}{c}\text { Виробничі } \\
\text { витрати на } 1 \\
\text { люд.-год } \\
\end{array}$ & $\begin{array}{c}\text { Витрати } \\
\text { ел.енергії } \\
\text { на } 1 \text { люд.-год } \\
\end{array}$ \\
\hline $\begin{array}{c}\text { Кількість } \\
\text { працівників, } \\
\text { люд. } \\
\end{array}$ & $\begin{array}{c}\text { Рентабельність } \\
\text { праці }\end{array}$ & $\begin{array}{c}\text { Продук- } \\
\text { тивність праці, } \\
\text { грн } \\
\end{array}$ & $\begin{array}{c}\text { Продук- } \\
\text { тивність праці, } \\
\text { кг/люд } \\
\end{array}$ & $\begin{array}{l}\text { Витрати кор- } \\
\text { мів на } 1 \text { праці- } \\
\text { вника } \\
\end{array}$ & $\begin{array}{c}\text { Продук- } \\
\text { тивність праці } \\
\text { за собівартістю } \\
\end{array}$ & $\begin{array}{c}\text { Енерго- } \\
\text { озброєність } 1 \\
\text { працівника } \\
\end{array}$ \\
\hline $\begin{array}{l}\text { Виробнича } \\
\text { площа, } \text { м }^{2}\end{array}$ & $\begin{array}{c}\text { Прибуток } \\
\text { на } 1 \text { м }^{2}\end{array}$ & $\begin{array}{l}\text { Виторг } \\
\text { на } 1 \mathrm{~m}^{2}\end{array}$ & $\begin{array}{c}\text { Вироблено } \\
\text { продукції на } 1 \\
\text { м }^{2} \\
\end{array}$ & $\begin{array}{c}\text { Витрати кор- } \\
\text { мів } \\
\text { на } 1 \text { м }^{2} \\
\end{array}$ & $\begin{array}{c}\text { Виробничі } \\
\text { витрати } \\
\text { на } 1 \text { м }^{2} \\
\end{array}$ & $\begin{array}{c}\text { Витрата ел. } \\
\text { енергії на } 1 \text { м² }\end{array}$ \\
\hline
\end{tabular}

Для оцінювання економічної ефективності кормовиробництва у тваринництві використовують показник "граничної продуктивності кормової (кормопротеїнової) одиниці”, який визначають за формулою:

$$
\Pi_{\text {гр }}=\frac{\bigsqcup_{\mathrm{T}}-Ц_{\mathrm{T}} \times(1-\lambda)}{\kappa_{\text {к.од. }}}
$$

де:

$\Pi_{г р}-$ гранична вартість кормової одиниці, грн;

$Ц_{\mathrm{T}}$ - ціна продукції тваринництва, грн;

$\boldsymbol{\lambda}$ - частка кормів у структурі витрат;

$K_{\text {к.од. }}-$ витрати кормів на одиницю продукції тваринництва.

Економічну ефективність молочного скотарства доцільно розглядати з позиції: перше - системи факторів інтенсифікації, які впливають на розвиток галузі; друге - одержання результату на основі раціонального використання виробничого потенціалу; третє максимізації віддачі вкладеного капіталу та мінімізації негативного впливу виробничої діяльності на на- вколишнє природне середовище; забезпечення відповідних умов проживання сільського населення й забезпечення науково обгрунтованих норм споживання молока та молочної продукції (Radko \& Svynous, 2015).

Для оцінки продуктивного використання молочних корів використовують коефіцієнт інтенсивності продуктивності (КІП), який розраховують відношенням середнього надою за одну добу до пожиттєвого надою корови:

$$
\text { кПВ }=\frac{Д \mathrm{H}+Ж_{\mathrm{B}}+Ж_{\Pi}+Ж_{\text {мо }}}{\mathrm{T} Ж-\mathrm{BO}}
$$

де:

ДН - довічний надій молока за \% жирності (білка), кг;

ЖВ $\mathrm{B}_{\mathrm{M}}$ - жива маса при вибутті корови, кг;

ЖМ

ЖМ

ТЖ - тривалість життя, дні;

ВО - вік першого отелення, дні. 
Прогнозовану собівартість виробництва молока розраховують за формулою:

$$
y=\frac{a \times 100}{b} \times 0,806 / x
$$

де:

у - прогнозована собівартість 1 ц молока, грн;

a - загальна вартість кормів на корову в рік, грн;

b - частка кормів, залежно від надоїв молока в структурі загальних витрат на корову, \%;

x - надій молока від корови за рік, ц;

0,806 - постійний коефіцієнт витрат на молоко 3 усіх виробничих витрат на корів.

Прогнозовану собівартість вирощування 1 ц приросту живої маси молодняку ВРХ визначають за таким рівнянням:

$$
y=\frac{a \times 100}{b} \times 0,96 / x
$$

де:

у - прогнозована собівартість 1 ц приросту, грн;

$a$ - загальна вартість кормів на одну середньорічну голову молодняку ВРХ, грн;

$b$ - частка кормів, залежно від середньодобових приростів живої маси в структурі загальних витрат на одну голову молодняку ВРХ, \%;

$x$ - приріст на середньорічну голову, ц;

0,96 - постійний коефіцієнт витрат на приріст 3 усіх виробничих витрат на молодняк ВРХ.

Українське тваринництво повинно розвиватися шляхом збільшення кількості тваринницьких ферм за рахунок дрібних комплексних господарств та екстенсивних систем із низьким споживанням зовнішніх виробничих ресурсів (Zamlynskyi, 2019).

Комплексність механізації тваринництва, окремих технологічних ліній чи конкретних машин і обладнання визначають за розрахунковими технікоекономічними показниками, порівнюючи їх з отриманими на практиці показниками діючого об'єкту чи базового аналога або з показниками кращих зразків вітчизняної чи світової практики (табл. 2).

Таблиця 2

\begin{tabular}{|c|c|c|}
\hline Назва & Формула & Необхідні дані \\
\hline Витрати праці & $\begin{array}{c}\text { добові } \\
3_{\text {д }}=\mathrm{t}_{\mathrm{i}} \times \mathrm{N}_{\text {обі }} \times \mathrm{n}_{\mathrm{Mi}} \\
\text { річні } \\
3_{\mathrm{p}}=3_{д} \times \mathrm{Dpj}\end{array}$ & $\begin{array}{l}\mathrm{t}_{\mathrm{i}} \text { - тривалість роботи і-го операційного обладнання протягом доби, год; } \\
\mathrm{N}_{\text {oбi }} \text { - кількість персоналу, що обслуговує дане операційне обладнання, чоло- } \\
\text { вік; } \\
\mathrm{n}_{\text {мі }} \text { - кількість машин, які виконують дану операцію, шт.; } \\
\mathrm{D}_{\mathrm{p}} \text { - кількість днів, протягом яких повторюється ј-та операція протягом року. }\end{array}$ \\
\hline $\begin{array}{l}\text { Експлуатаційні } \\
\text { витрати }\end{array}$ & $\mathrm{C}=\mathrm{O}_{\Pi}+\mathrm{E}+\mathrm{A}+\mathrm{P}$ & $\begin{array}{l}\mathrm{O}_{\text {п }} \text { - оплата праці робітників, грн.; } \\
\text { Е - вартість споживаних енергоресурсів, грн.; } \\
\text { А - амортизаційні відрахування (на реновацію технічних засобів), грн.; } \\
\text { Р - відрахування на ремонт і технічне обслуговування машин та обладнання, } \\
\text { грн. }\end{array}$ \\
\hline Амортизація & $\begin{array}{l}A=a \times b_{M} \times k_{B} \\
P=p \times b_{M} \times k_{B}\end{array}$ & $\begin{array}{l}\text { a i p - нормативні частки відрахувань від балансової вартості; } \\
\text { Бм - обладнання відповідно на амортизацію, технічне обслуговування і ре- } \\
\text { монт машин; } \\
\text { k }_{\text {в - коефіцієнт використання засобів механізації. }}\end{array}$ \\
\hline $\begin{array}{l}\text { Питома } \\
\text { енергоємність }\end{array}$ & $\begin{array}{l}\mathrm{q}_{\Pi}=\mathrm{W}_{\text {рп }} / \mathrm{Q} ; \\
\mathrm{q}_{п р}=\mathrm{W}_{\text {річ }} / \Pi\end{array}$ & $\begin{array}{l}\text { qп i qпр - питома енергоємність відповідно технологічного процесу та вироб- } \\
\text { леної продукції кВт/кг; } \\
\mathrm{W}_{\text {рп }} \text { i } \mathrm{W}_{\text {річ }} \text { - витрати енергії відповідно на виконання даного технологічного } \\
\text { процесу та на все виробництво, кВт. }\end{array}$ \\
\hline $\begin{array}{l}\text { Питома } \\
\text { металомісткість }\end{array}$ & $\begin{array}{c}\mathrm{T}_{\text {оп }}=\Sigma \mathrm{M}_{\text {опі }} / \mathrm{Q} ; \\
\mathrm{T}_{\text {пр }}=\Sigma \mathrm{M} / \Pi\end{array}$ & 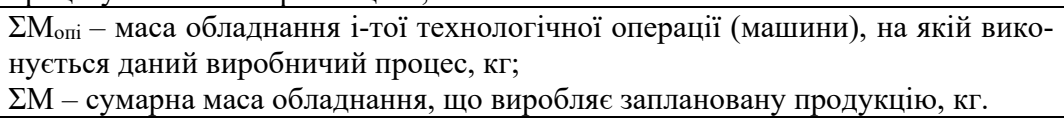 \\
\hline $\begin{array}{l}\text { Економічний } \\
\text { ефект }\end{array}$ & $\begin{array}{c}\mathrm{E}_{\mathrm{p}}=\left(\mathrm{c}_{1}+\mathrm{E}_{\mathrm{H}} \times \mathrm{K} 1\right)- \\
\left(\mathrm{c}_{2}+\mathrm{EH}_{\mathrm{H}} \times \mathrm{K} 2\right)\end{array}$ & $\begin{array}{l}\text { с с і с } \text { c }_{2} \text { річні експлуатаційні витрати на виробництво одиниці продукції від- } \\
\text { повідно за базовим та спроектованим варіантами, грн.; } \\
\text { К }_{1} \text { і К К - сума капіталовкладень у відповідних варіантах, грн.; } \\
\mathrm{E}_{\mathrm{H}}-\text { нормативний коефіцієнт ефективності капіталовкладень, } \mathrm{E}_{\mathrm{H}}=0,15 \text {. }\end{array}$ \\
\hline $\begin{array}{l}\text { Окупність } \\
\text { капіталовкладень }\end{array}$ & $\mathrm{P}=\left(K_{1}-K_{2}\right) / E_{p}$ & $\begin{array}{l}\text { K }_{1} \text { і К } \\
\text { E }_{p} \text { - екома капіталовкладень у відповідних варіантах, грн.; }\end{array}$ \\
\hline
\end{tabular}

Показники техніко-економічної ефективності механізації виробничих процесів у тваринництві

Застосування розглянутих вище показників аналізу та оцінки ефективності тваринництва дозволить забезпечити:

- оцінку ефективності систем ведення виробництва тваринницькими підприємствами в сучасних умовах їх розвитку;

- об'єктивну характеристику ведення господарства та головних результатів діяльності в тваринництві;
- $\quad$ визначення найбільш раціональних варіантів підвищення ефективності тваринництва;

- порівняльну оцінку ефективності тваринницьких підприємств, що працюють в однакових природно-економічних умовах;

- вимір ефективності виробництва у тваринництві та суміжних галузях; виявлення та оцінку комплексу заходів розвитку тваринництва, спрямованих на підвищення ефективності його функціонування. 


\section{Висновки}

Отже, економічна ефективність тваринництва є складною і багатогранною категорією, не має однозначного трактування та визначення в науковій літературі, залежить від обгрунтованого співвідношення витрат і результатів виробництва. Значну увагу при науковому аналізі та оцінці варто звернути на визначення ефективності роботи тваринницьких підприємств як завершального етапу фінансового та управлінського аналізу господарської діяльності аграрних формувань.

\section{References}

Andriichuk, V. H. (2016). Sutnisnyi aspekt metodolohii naukovykh doslidzhen. Ekonomika APK, 7, 87-93 (in Ukrainian).

Kostetskyi, Ya. I. (2013). Statystychnyi analiz efektyvnosti diialnosti silskohospodarskykh tovarovyrobnykiv. Innovatsiina ekonomika, 2, 338341 (in Ukrainian).

Livinskyi, A. (2019). Suchasni metodychni pidkhody do efektyvnosti stratehichnoi diialnosti pidpryiemstv tvarynny-tstva. Ekonomichnyi analiz, 29(1), 141-148. doi: 10.35774/econa2019.01 (in Ukrainian).

Lysenko, M. I., \& Lysenko, A. M. (2009). Metodychni pidkhody do otsinky efektyvnosti vyrobnytstva $u$ silskohospo-darskykh pidpryiemstvakh. Naukovi pratsi KNTU. Ekonomichni nauky, 16(1), 126-131 (in Ukrainian).

Petrychenko, O. A., \& Petrychenko, I. I. (2017). Orhanizatsiia kormozabezpechennia molochnoho skotarstva. Ahrosvit, 19-20, 63-68 (in Ukrainian).

Radko, V. I., \& Svynous, I. V. (2015). Metodychni pidkhody do vyznachennia efektyvnosti intensyfikatsii molochnoho skotarstva. Ekonomichna dumka. Investytsii: praktyka ta dosvid, 23, 53-57. doi: 10.32702/2306-6814.2021.6.5 (in Ukrainian).

Shpykuliak, O. H., \& Malik, M. Y. (2019). Instytutsionalnyi analiz rozvytku pidpryiemnytstva $\mathrm{V}$ ahrarnomu sektori ekonomiky: metodychnyi aspekt. Ekonomika APK, 6, 73-82. doi: 10.32317/22211055.201906073 (in Ukrainian).

Zamlynskyi, V. A. (2019). Strukturni peretvorennia haluzi tvarynnytstva $\mathrm{v}$ konteksti hlobalnoi prodovol-choi bezpeky. Ekonomika APK, 4, 22-28. doi: 10.32317/2221-1055.201904022 (in Ukrainian). 